\title{
DID THE 2002 HAYMAN FIRE, COLORADO, USA, BURN WITH UNCHARACTERISTIC SEVERITY?
}

\author{
Paula J. Fornwalt ${ }^{*}$, Laurie S. Huckaby ${ }^{1}$, Steven K. Alton ${ }^{2}$, Merrill R. Kaufmann', \\ Peter M. Brown ${ }^{3}$, and Antony S. Cheng ${ }^{4}$ \\ ${ }^{1}$ USDA Forest Service, Rocky Mountain Research Station, \\ 240 West Prospect Road, Fort Collins, Colorado 80526, USA \\ ${ }^{2}$ USDA Forest Service, Rocky Mountain Research Station, \\ 232 County Road 79, Woodland Park, Colorado 80863, USA \\ ${ }^{3}$ Rocky Mountain Tree-Ring Research, \\ 2901 Moore Lane, Fort Collins, Colorado 80526, USA \\ ${ }^{4}$ Colorado Forest Restoration Institute, Colorado State University, \\ 1472 Campus Delivery, Fort Collins, Colorado 80523, USA
}

"Corresponding author: Tel.: +1-970-498-2581; e-mail: pfornwalt@fs.fed.us

\begin{abstract}
There is considerable interest in evaluating whether recent wildfires in dry conifer forests of western North America are burning with uncharacteristic severity - that is, with a severity outside the historical range of variability. In 2002, the Hayman Fire burned an unlogged 3400 ha dry conifer forest landscape in the Colorado Front Range, USA, that had been the subject of previous fire history and forest age structure research. We opportunistically leveraged pre-existing data from this research, in combination with post-fire aerial imagery, to provide insight into whether the Hayman Fire's patterns of high-severity, stand-replacing fire effects were uncharacteristic. Living old overstory trees were well distributed and abundant in the landscape before the Hayman Fire, despite the fact that some stand-replacing burning had been a component of the landscape's histori-
\end{abstract}

RESUMEN

Existe un considerable interés por evaluar si incendios recientes en bosques de coníferas de áreas secas del oeste de Norte América se están quemando con una severidad poco característica, es decir si esta severidad está por fuera de su rango de variabilidad histórica. En 2002, el incendio Hayman quemó 3400 ha de bosques secos de coníferas en la cordillera frontal de Colorado, EEUU, que había sido objeto de investigaciones previas sobre su historia de fuego y sus características de edad y estructura. Nosotros aprovechamos la oportunidad para impulsar una investigación con datos pre-existentes, en combinación con imágenes aéreas satelitales post-fuego, para tener una visión sobre si los patrones de alta severidad y efectos de reemplazo total de rodales del incendio Hayman fueron no característicos (fuera de su rango histórico de variabilidad). Los árboles viejos, dominantes del dosel superior, estaban bien distribuidos y eran abundantes antes del incendio Hayman, a pesar del hecho que algún incendio de reemplazo del rodal 
cal mixed-severity fire regime. Of 106 randomly selected stand polygons that were sampled for the age of the oldest living overstory tree prior to the fire, $30 \%$ contained only trees $\leq 200 \mathrm{yr}$, while $70 \%$ contained at least one tree $>200 \mathrm{yr}$ and $29 \%$ contained at least one tree $>400$ yr. Following the Hayman Fire, only $5 \%$ of the polygons contained any living trees; these polygons were all immediately adjacent to the reservoir in the center of the landscape. At most, $4 \%$ of the polygons contained one or more trees $>200 \mathrm{yr}$ post fire, and $3 \%$ contained one or more trees $>400$ yr. The nearly complete loss of old trees, most of which were located in areas with evidence of past non-stand-replacing burning, leads us to conclude that the amount and extent of stand-replacing burning within the Hayman Fire were uncharacteristic for this landscape over at least the last two to four centuries. había sido un componente del paisaje en un régimen de fuego histórico de severidad mixta. De los 106 polígonos de rodales elegidos al azar que fueron muestreados por edades de los árboles más viejos previos al fuego, el $30 \%$ presentó árboles $\leq 200$ años, mientras que el $70 \%$ presentó al menos un árbol $>200$ años, y $29 \%$ presentó al menos un árbol $>400$ años. Después del incendio Hayman, solo un $5 \%$ de los polígonos presentaban árboles vivos; esos polígonos, estaban todos inmediatamente adyacentes al reservorio en el centro del paisaje. Cuanto mucho, 4\% de los polígonos tenían uno o más árboles >200 años post fuego y $3 \%$ tenían uno o más árboles $>400$ años. La pérdida casi completa de árboles añejos, la mayoría de los cuales estaban ubicados en áreas con evidencias de incendios pasados poco severos, nos lleva a concluir que la cantidad y el grado de extensión de incendios de reemplazo de rodales en el incendio Hayman fueron no característicos en este paisaje por al menos los dos a cuatro últimos siglos.

Keywords: Colorado Front Range, Hayman Fire, high-severity fire effects, historical range of variability, old trees, Pinus ponderosa Lawson \& C. Lawson, ponderosa pine, stand-replacing fire effects

Citation: Fornwalt, P.J., L.S. Huckaby, S.K. Alton, M.R. Kaufmann, P.M. Brown, and A.S. Cheng. 2016. Did the 2002 Hayman Fire, Colorado, USA, burn with uncharacteristic severity? Fire Ecology 12(3): 117-132. doi: 10.4996/fireecology.1203117

\section{INTRODUCTION}

Dry conifer forests across western North America have experienced considerable wildfire activity in recent decades (Westerling et al. 2006, Miller et al. 2009, Dillon et al. 2011, Miller and Safford 2012, Westerling 2016). Many of these recent wildfires burned with high severity across a sizable portion of their footprint, creating vast stand-replacing patches devoid of surviving overstory trees. In the United States, for example, Colorado's 2002 Hayman Fire, Arizona's 2011 Wallow Fire, and California's 2013 Rim Fire - among the largest and most severe wildfires known to have occurred in their respective states - each created stand-replacing patches many thousands of hectares in size (Finney et al. 2003, Waltz et al. 2014, Steel et al. 2015). Western dry conifer forests that burned with stand-replacing severity in recent wildfires have often had deleterious post-fire ecological responses, such as increased soil erosion, diminished tree regeneration, and elevated exotic plant invasions relative to forests that burned less severely (Benavides-Solorio and MacDonald 
2001, Keyser et al. 2008, Fornwalt et al. 2010, Chambers et al. 2016), generating concern that stand-replacing burning threatens their sustainability.

The historical range of variability (HRV) is widely viewed as a useful concept for characterizing the range of properties and processes that sustained ecosystems in the past, and for identifying potential threats to sustainability due to recent departures from past conditions (Morgan et al. 1994, Landres et al. 1999, Keane et al. 2009). Thus, there is considerable interest in evaluating whether the fire severity patterns of recent wildfires in Western dry conifer forests - and high-severity, stand-replacing patterns in particular-have departed from HRV. Numerous studies in these forests have documented historical (typically defined as prior to Euro-American settlement) fire regimes that consisted primarily of low-severity wildfires, with little or no stand-replacing burning, as well as primarily of mixed-severity wildfires, sometimes with a substantial stand-replacing component (e.g., Baisan and Swetnam 1990; Fulé et al. 1997, 2005; Brown et al. 1999, 2008, 2015; Fulé and Covington 1999; Everett et al. 2000; Beaty and Taylor 2001; Sherriff and Veblen 2006, 2007; Iniguez et al. 2009; Scholl and Taylor 2010; Heyerdahl et al. 2012; Williams and Baker 2012; Sherriff et al. 2014; Stephens et al. 2015). Yet, few studies have contrasted historical and current patterns of stand replacement. One such study was conducted by Harris and Taylor (2015) for a 2125 ha dry conifer forest landscape in Yosemite National Park, California, USA. The authors found that none of their pre-existing plots contained evidence of historical stand-replacing burning, yet $24 \%$ of them experienced stand-replacing or nearly stand-replacing burning in the 2013 Rim Fire, due to increased forest density following more than a century of fire exclusion. Additional studies such as this are needed to gain a more thorough understanding of how the stand-replacing component of recent wildfires compares to that of historical ones.
Dry conifer forests of Colorado's Front Range, USA, have experienced numerous wildfires in recent decades, paralleling trends observed across the West (Graham et al. 2012). Although it is widely held that these forests were historically regulated by mixed-severity fire regimes at all but the lowest elevations (e.g., Brown et al. 1999, 2015; Sherriff and Veblen 2006, 2007; Williams and Baker 2012; Sherriff et al. 2014), uncertainty remains regarding whether the patterns of stand-replacing burning of recent wildfires have departed from HRV. In 2002, the Hayman Fire burned across an unlogged 3400 ha dry conifer forest landscape that had been the subject of previous fire history and forest age structure research (Figure 1; Brown et al. 1999; Kaufmann et al. 2000, 2001; Huckaby et al. 2001). We opportunistically leveraged overstory tree age data from this past research - in particular, the ages of the oldest trees within sampled stands, which give some indication of how long the stands have persisted without complete stand-replacing disturbance - in combination with post-fire aerial imagery, to calculate metrics describing the age, abundance, and distribution of the oldest trees before and after the fire. We then interpreted these metrics in the context of the landscape's fire history to provide insight into whether the stand-replacing component of the Hayman Fire was uncharacteristic relative to fires that burned in the past.

\section{METHODS}

\section{Study Area}

Our study area was the 3400 ha Cheesman Lake landscape, both before and after the 2002 Hayman Fire (Figures 1, 2). The Cheesman Lake landscape is located approximately 60 $\mathrm{km}$ southwest of Denver, Colorado, USA, and encompasses Cheesman Lake, a 350 ha reservoir on the South Platte River. The landscape has been owned by Denver Water (or its predecessors) since the early 1890s. Elevations 


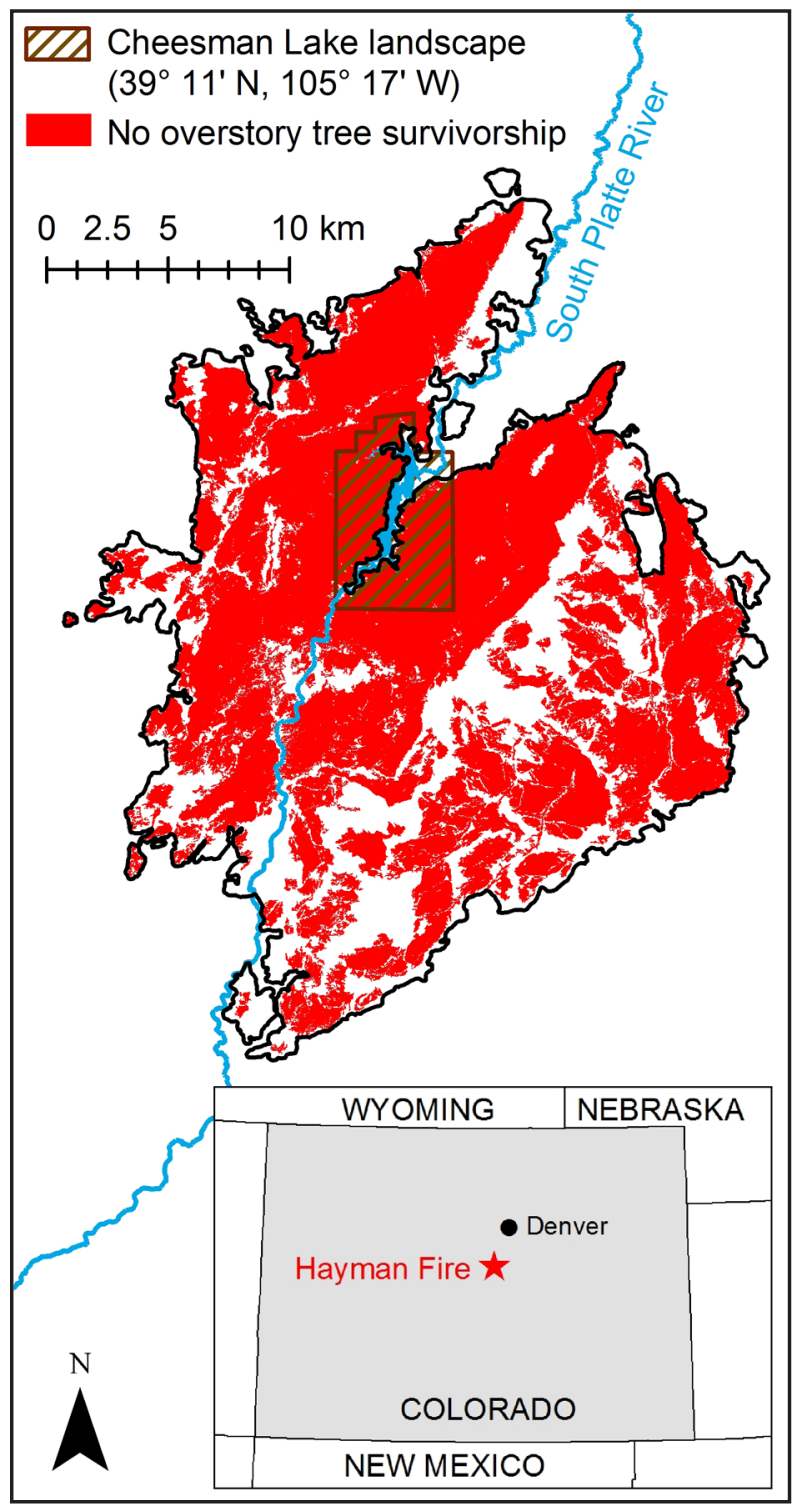

Figure 1. The location of the Cheesman Lake landscape within the 2002 Hayman Fire, Colorado, USA. Areas in red represent post-fire patches that were devoid of surviving overstory trees, and were derived from aerial imagery taken in 2013 (adapted from Chambers et al. 2016). The inset shows the location of the Hayman Fire within Colorado.

range from $2100 \mathrm{~m}$ to $2400 \mathrm{~m}$. Annual precipitation averages about $38 \mathrm{~cm}$ at nearby Manitou Experimental Forest. Soils are primarily gravelly coarse sandy loams derived from Pikes Peak granite. Forest overstories prior to the Hayman Fire were generally dominated by ponderosa pine (Pinus ponderosa Lawson \&
C. Lawson) on south-facing slopes, and by ponderosa pine and Douglas-fir (Pseudotsuga menziesii [Mirb.] Franco) on north-facing slopes (Kaufmann et al. 2000). Diverse communities of graminoids, forbs, and shrubs characterized the pre-fire forest understory (Fornwalt et al. 2003, 2009).

Prior to the Hayman Fire, the Cheesman Lake landscape had been only minimally impacted by land use activities such as logging and livestock grazing (Kaufmann et al. 2000; Fornwalt et al. 2003, 2009). Deliberate protection from such activities made the landscape unique relative to surrounding lands on which logging and livestock grazing had been intense, particularly in the decades immediately following Euro-American settlement in the late 1800s. Some logging occurred during dam construction from 1894 to 1905 , but it was largely restricted to areas now below the waterline of the reservoir. Upon completion of the dam, a fence was constructed around the landscape to prevent trespassing from loggers and livestock and to limit recreation.

In contrast to the landscape's land use history, its fire history prior to the Hayman Fire was generally reflective of surrounding lands. An eight-century-long fire history constructed from tree-ring data showed that this landscape historically experienced a mixed-severity fire regime (Brown et al. 1999). Widespread wildfires (burning $\sim 1000$ ha or more of the landscape) occurred every $27 \mathrm{yr}$ to $128 \mathrm{yr}$ before Euro-American settlement and averaged $59 \mathrm{yr}$ between events. Less extensive wildfires were more frequent, such that a wildfire occurred somewhere on the landscape every 1 yr to 29 yr and every $9 \mathrm{yr}$ on average. The severity of widespread wildfires varied from low to high, with stand-replacing patches estimated to be no larger than about 100 ha (Brown et al. 1999, Kaufmann et al. 2000, Romme et al. 2003). This range of severity was especially apparent during the 1851 fire year (Brown et al. 1999). The year 1851 was an extremely dry year that followed the longest period with- 


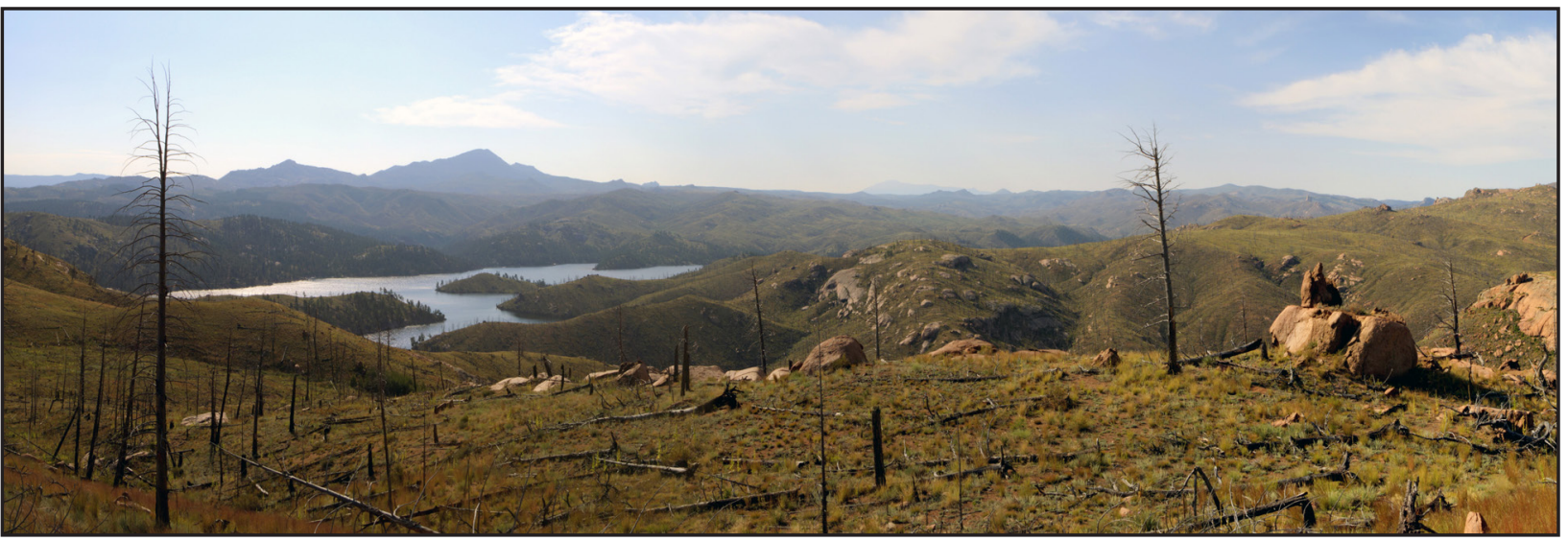

Figure 2. The Cheesman Lake landscape 13 yr following the 2002 Hayman Fire. This photograph was taken from near the north end of the property. Living trees are apparent only adjacent to the reservoir. Photograph by P.M. Brown.

out a widespread wildfire on the landscape, and burning in this year is thought to have created more and larger patches of stand-replacing fire effects than other historical wildfires. A fire suppression policy has been in place since the early 1900s, and the landscape did not experience a widespread wildfire from 1851 until the 2002 Hayman Fire.

The Hayman Fire was ignited on 8 June 2002. Driven by low relative humidity, strong winds, and heavy and continuous fuels, the Hayman Fire ran $\sim 30 \mathrm{~km}$ on 9 June, burning predominately with stand-replacing effects (Bradshaw et al. 2003, Finney et al. 2003). The Cheesman Lake landscape is estimated to have burned in the latter half of this day (Finney et al. 2003). Less extreme weather conditions arrived on 10 June and persisted for much of the next three weeks, and fire severity patterns were somewhat more spatially heterogeneous. The Hayman Fire was contained on 2 July, after having burned more than 52000 ha of predominately dry conifer forest. Approximately $83 \%$ of the Cheesman Lake landscape is within the Hayman Fire perimeter (MTBS 2015); unburned portions of the landscape are comprised primarily of the reservoir and land immediately adjacent to it.

\section{Data Collection and Analysis}

Our study leverages the pre-fire overstory tree age dataset of Huckaby et al. (2001), which was collected to characterize the age structure of the oldest living overstory trees in the Cheesman Lake landscape. To derive this dataset, the landscape was first manually mapped by drawing polygons around areas with homogeneous overstory tree canopy cover and tree size distributions (i.e., stands) on 1:6000 color-infrared print aerial imagery taken in 1996. The polygons were digitized and orthorectified, and approximately $10 \%$ of them were randomly selected for field sampling. Approximately five living overstory trees $(>10 \mathrm{~cm}$ diameter at breast height) that appeared to be the oldest, or to represent the oldest cohort, were cored in each polygon in 1999 at $\sim 35 \mathrm{~cm}$ above the ground. The oldest trees were identified by the distinctive morphological characteristics that develop with age (Huckaby et al. 2003). The presence of visibly fire-scarred trees was also noted for each polygon during field sampling. In the laboratory, germination dates of sampled trees were determined by crossdating cores with an existing ring-width chronology to obtain dates for the innermost tree-rings (Stokes and Smiley 1968, Brown et al. 1999), using an overlay 
of concentric circles to estimate pith dates from the innermost dates when the core did not intercept the pith (Applequist 1958), and adjusting pith dates for the approximate time required to grow to coring height ( $5 \mathrm{yr}$ to $18 \mathrm{yr}$ depending on species and site productivity; Kaufmann et al. 2000).

We used ArcMap 10.2 (Environmental Systems Research Institute, Redlands, California, USA) and $1 \mathrm{~m}$ resolution orthorectified color digital aerial imagery taken in 2013 to "revisit" the 106 sampled polygons that were $>0.25$ ha and that were fully within the Hayman Fire perimeter (mean polygon area of $2.85 \pm 0.44$ ha; Figure 3; MTBS 2015, NAIP 2015). We estimated the percent of each polygon that burned with stand replacement by dividing the polygon's stand-replaced area, determined using the "measure" tool in ArcMap, by its total area. Only contiguous areas of complete overstory tree mortality $>0.25$ ha were considered in our estimates of stand replacement. Smaller areas of mortality were viewed as pockets of severe fire (i.e., torching of a single tree or small group of trees) within larger patches of lesser fire severity, and were disregarded.

We used the stand-replacement estimates in combination with the tree age dataset to calculate metrics describing the pre-fire and postfire age, abundance, and distribution of the oldest living trees, and we compared pre-fire and post-fire values using repeated measures analysis of variance in SAS 9.4 (PROC GLIMMIX; SAS Institute Inc., Cary, North Carolina, USA). We conservatively assumed that sampled trees died only if the entire polygon experienced stand-replacing effects. This assumption was necessary because we did not know the full age structure for the polygons, nor the exact locations of the sampled trees. Tree ages were calculated for 2002, the year of the Hayman Fire.

\section{RESULTS}

A total of 502 living overstory trees were successfully aged by Huckaby et al. (2001) across the 106 polygons analyzed here, with $47 \%$ of the trees $>200 \mathrm{yr}$ at the time of the 2002 Hayman Fire, and $11 \%$ of the trees $>400$ yr. The oldest tree encountered was a $>600 \mathrm{yr}$ ponderosa pine, which germinated around 1395. All polygons contained living trees. Of the 106 polygons, $30 \%$ contained only trees $\leq 200 \mathrm{yr}, 70 \%$ contained one or more trees $>200 \mathrm{yr}$, and $29 \%$ contained one or more trees $>400$ yr (Figures 4, 5). The distance between a sampled polygon and the nearest polygon with one or more trees $>200 \mathrm{yr}$ and $>400 \mathrm{yr}$ averaged $132 \mathrm{~m}$ and $304 \mathrm{~m}$, respectively (Figure 6). Visibly fire-scarred trees were noted in $4 \%$ of the polygons in which all trees were $\leq 200 \mathrm{yr}$, in $44 \%$ of polygons in which one or more trees was $>200 \mathrm{yr}$, and in $63 \%$ of polygons in which one or more trees was $>400 \mathrm{yr}$.

The Hayman Fire burned with complete stand replacement in $95 \%$ of the polygons, killing all overstory trees within them. The remaining $5 \%$ of the polygons experienced $50 \%$ to $90 \%$ stand replacement. All polygons with surviving trees were within $50 \mathrm{~m}$ of Cheesman Lake.

At least $96 \%$ of the trees sampled prior to the Hayman Fire, and $93 \%$ of the trees $>200$ $\mathrm{yr}$, did not survive the burn. The $>600 \mathrm{yr}$ ponderosa pine was among the trees that perished in the fire. Following the fire, 1\% of the 106 polygons contained living trees that were all $\leq 200$ yr (a 32-fold reduction relative to pre-fire values; $P<0.001), 4 \%$ contained one or more trees $>200 \mathrm{yr}$ (an 18-fold reduction; $P<0.001$ ), and $3 \%$ contained one or more trees $>400 \mathrm{yr}$ (a 10 -fold reduction; $P<0.001$; Figures 4, 5). The average distance between a sampled polygon and the nearest polygon with one or more trees $>200 \mathrm{yr}$ increased 11 -fold to $1453 \mathrm{~m}$ post fire $(P<0.001)$, and the average distance between a sampled polygon and the nearest polygon with one or more trees $>400 \mathrm{yr}$ increased 5-fold to $1522 \mathrm{~m}(P<0.001$; Figure 6$)$. 

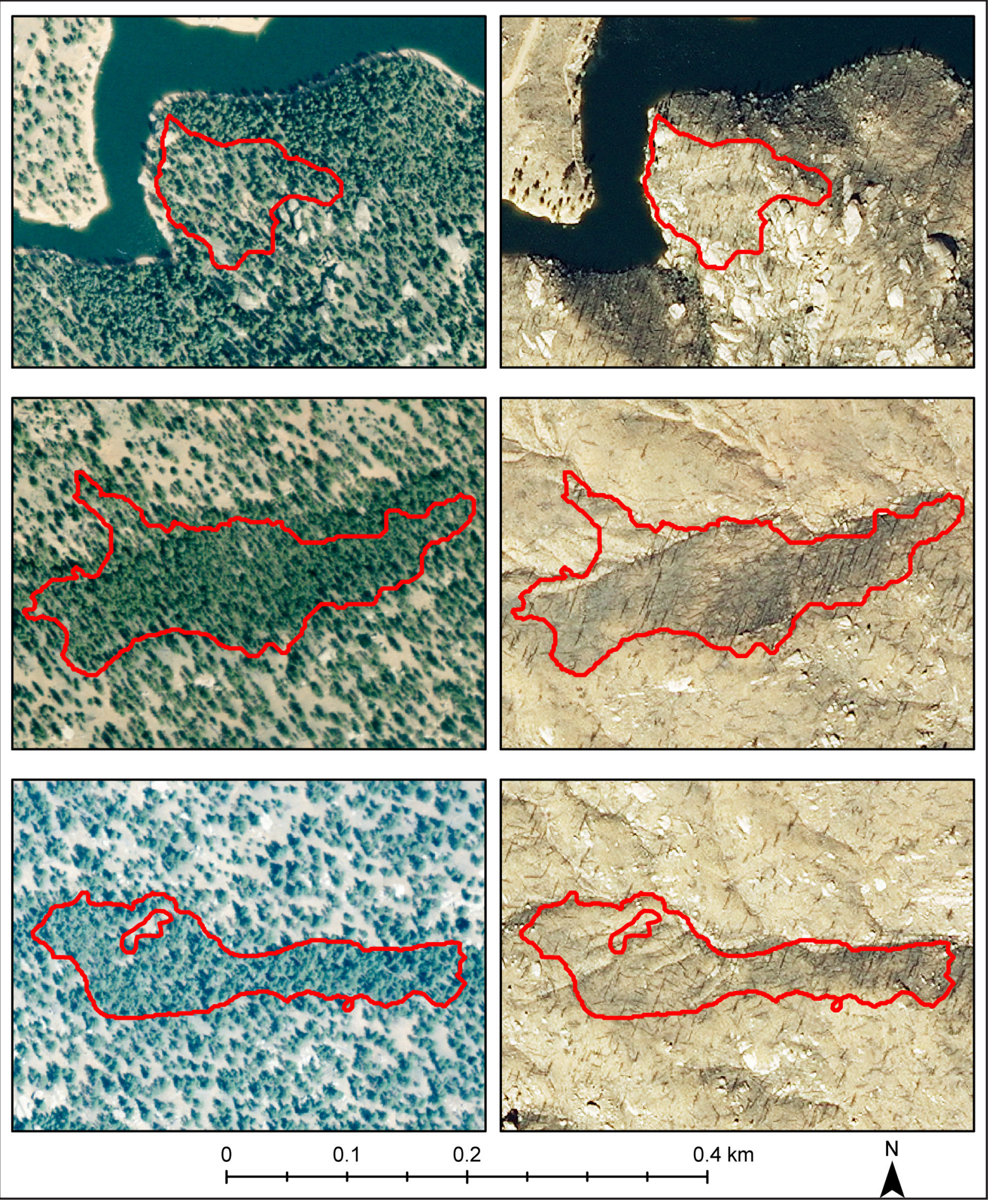

Figure 3. Example polygons at the Cheesman Lake landscape that experienced $100 \%$ stand replacement in the 2002 Hayman Fire. Pre-fire aerial imagery (left) was taken two months before the fire, and post-fire imagery (right) was taken in 2013. 
(a) Pre Hayman Fire

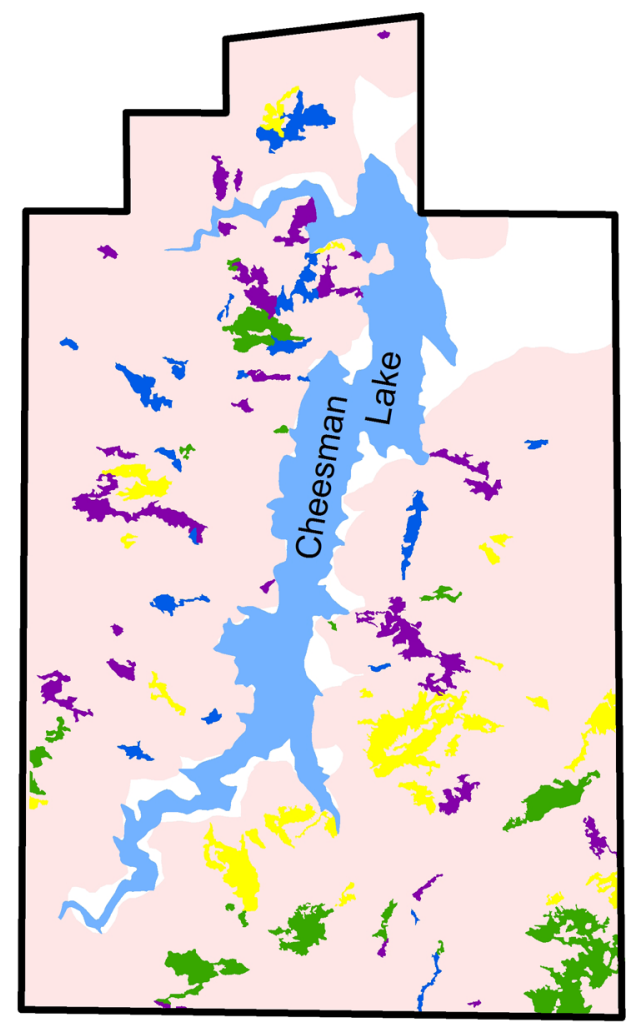

(b) Post Hayman Fire

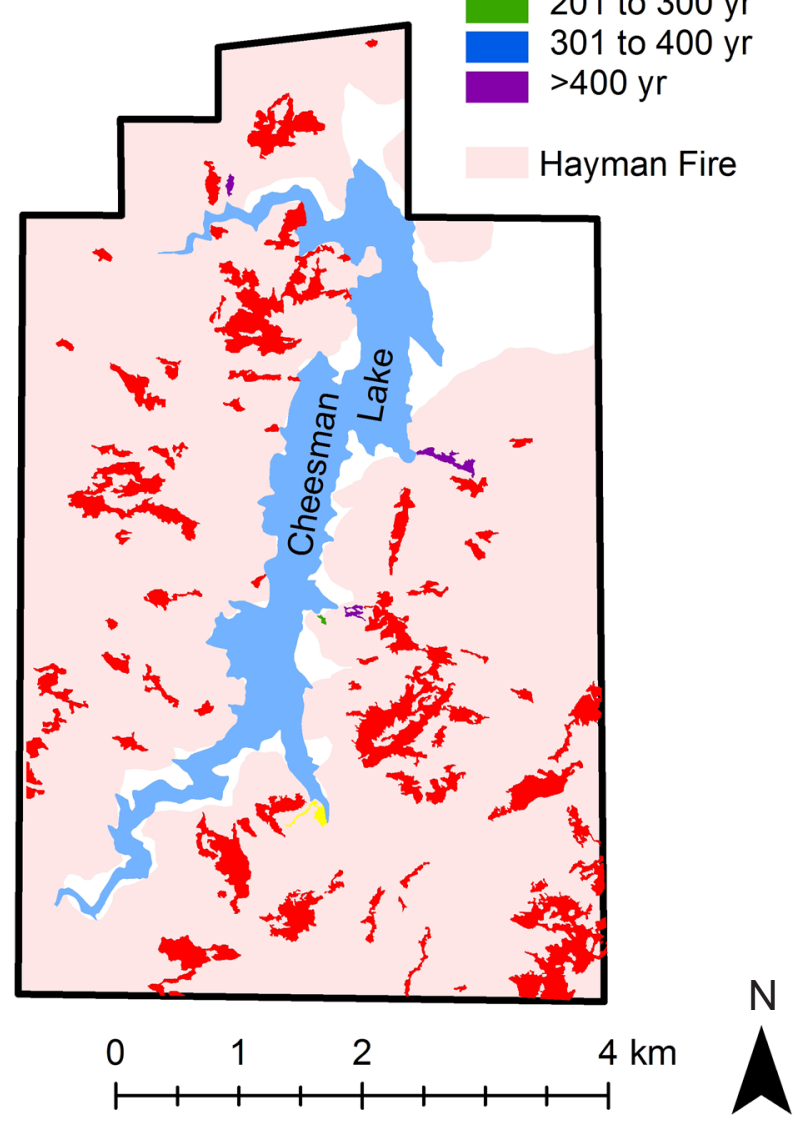

Figure 4. The Cheesman Lake landscape, with the age of the oldest living overstory tree in 106 polygons (a) before and (b) after the 2002 Hayman Fire.

\section{DISCUSSION}

The eight-century-long fire history developed by Brown et al. (1999) demonstrated that historical wildfires at the 3400 ha Cheesman Lake landscape left behind many surviving overstory trees, and the Huckaby et al. (2001) dataset corroborated this finding. Prior to the Hayman Fire, living old trees (i.e., $>200$ yr) were well distributed and abundant. More than two-thirds of the sampled polygons contained one or more trees $>200 \mathrm{yr}$, and nearly a third had one or more trees $>400 \mathrm{yr}$. The pres- ence of old trees in these polygons indicates that at least two to four centuries had passed since completely stand-replacing fire last occurred there, while the presence of visible fire scars in most of them indicates that one or more non-stand-replacing fires had burned there over that same time. Yet Brown et al. (1999) also found that some high-severity, stand-replacing burning was a component of the landscape's historical mixed-severity fire regime, as has likewise been found for other dry conifer forest landscapes across the broader Colorado Front Range and western North 


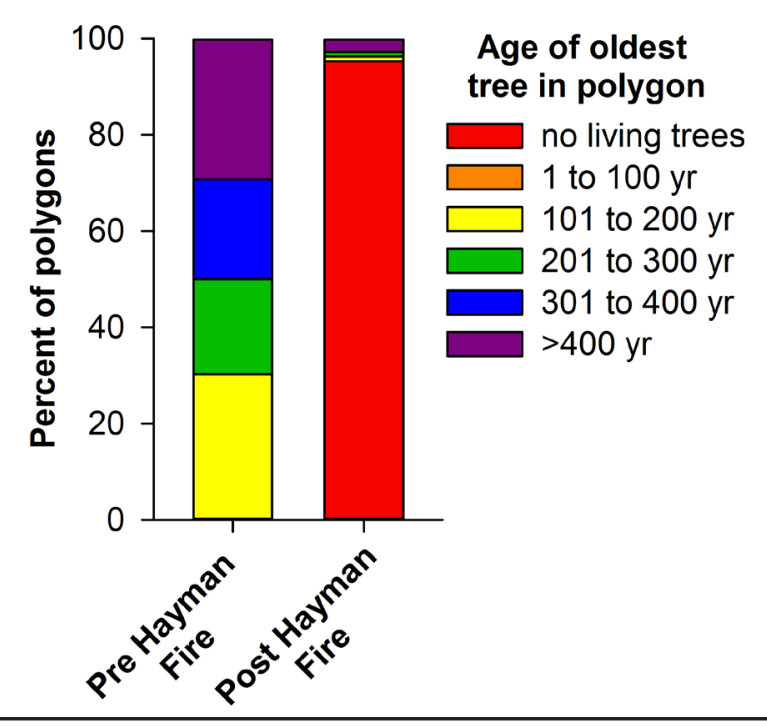

Figure 5. Ages of the oldest living overstory tree in 106 Cheesman Lake polygons, before and after the 2002 Hayman Fire.

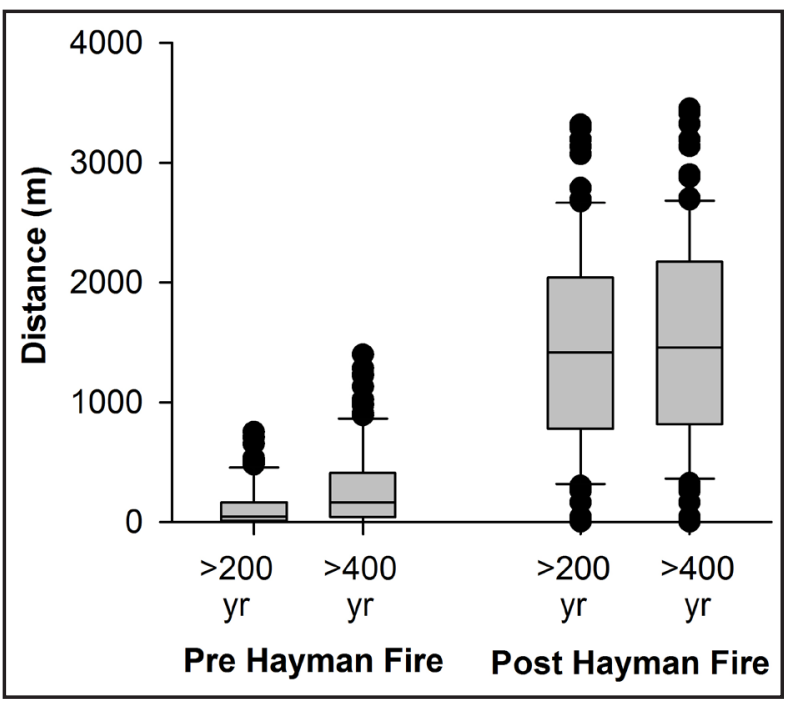

Figure 6. Box-and-whisker diagrams depicting the distance $(\mathrm{m})$ from each of the 106 Cheesman Lake polygons to the nearest polygon with one or more living overstory trees $>200 \mathrm{yr}$ and $>400 \mathrm{yr}$, before and after the 2002 Hayman Fire. Diagrams show medians, 25th and 75th percentiles (boxes), 10th and 90th percentile (whiskers), and outlier (points) distances.

America (Beaty and Taylor 2001; Sherriff and Veblen 2006, 2007; Iniguez et al. 2009; Hey- erdahl et al. 2012). Historical stand-replacing patches, estimated to be up to about 100 ha in size, were particularly concentrated in the southeast portion of the Cheesman Lake landscape and were a result of burning in the extremely dry year of 1851 (Brown et al. 1999, Kaufmann et al. 2000, Romme et al. 2003). This portion of the landscape also contained most of the pre-fire polygons in which the oldest tree was $\leq 200 \mathrm{yr}$, probably also indicating stand-replacing burning in the nineteenth century (fires in the twentieth century were largely eliminated due to fire exclusion).

While some stand-replacing burning occurred historically at the Cheesman Lake landscape, the amount and extent of historical stand-replacing burning pales in comparison to that within the 2002 Hayman Fire. The Hayman Fire caused complete overstory tree mortality in $95 \%$ of the polygons, with surviving trees only found in polygons immediately adjacent to the reservoir. If the $30 \%$ of polygons found to contain only trees $\leq 200 \mathrm{yr}$ prior to the Hayman Fire are treated as evidence of stand-replacing burning in the nineteenth century, then the Hayman Fire was responsible for over 3-fold more stand-replacing burning than all the fires in that century combined. Although our polygon data were not contiguous across the 3400 ha Cheesman Lake landscape, they nonetheless suggest that as much as 2700 ha of it burned as one large, stand-replacing patch - a patch size more than an order of magnitude larger than the maximum stand-replacing patch size estimated to have occurred in the past. Moreover, a Hayman-Fire-wide analysis of post-fire aerial imagery showed that about $70 \%$ of the fire's $>52000$ ha footprint is without surviving trees, that about $60 \%$ of this treeless area is in patches $>100$ ha, and that the Cheesman Lake landscape is in the center of a treeless patch $>20000$ ha in size, suggesting that much of this fire may have likewise burned in an uncharacteristically severe manner (Chambers et al. 2016). Recent wildfires in dry conifer forests of Arizona, Cal- 
ifornia, and New Mexico have similarly burned with a stand-replacing component that appears to be unprecedented in the historical record (O'Connor et al. 2014, Guiterman et al. 2015, Harris and Taylor 2015).

It should be noted that our finding regarding the Hayman Fire's severity contrasts with the finding of Sherriff et al. (2014), which indicated that the Hayman Fire burned in a manner consistent with HRV. While there are likely several explanations for this discrepancy, a principal one may be related to differences in how fire severity was classified. Sherriff et al. (2014) put low-severity fire regimes and fire effects, in which burning resulted in no to low overstory tree mortality, in a dichotomy with higher-severity regimes and effects, in which burning resulted in a greater level of mortality. They found that approximately $70 \%$ of the Hayman Fire's footprint historically experienced higher-severity fire, on par with the percent of the footprint that actually experienced higher-severity fire. Yet, by utilizing such a broad higher-severity class, they are unable to detect long-term changes in severity occurring within it, such as increases in stand-replacing burning. Utilizing this broad higher-severity class also provides only limited insight into post-fire ecological responses, as responses for forests that burned with stand-replacing effects are often very different than those for forests that burned with lesser severity. Post-fire tree regeneration in Western dry conifer forests, for instance, has been found to be markedly less abundant in areas with no surviving trees than in areas with some surviving trees, because regeneration is largely dependent on surviving trees for seed sources (Keyser et al. 2008, Chambers et al. 2016).

The uncharacteristic severity of the Hayman Fire and other recent wildfires in Western dry conifer forests is likely the product of multiple factors. Primary among them is the increase in forest density and homogeneity due to a century or more of fire exclusion (Fulé et al. 1997; Brown et al. 2008, 2015; Scholl and
Taylor 2010; Stephens et al. 2015). Indeed, only one wildfire of any notable size after Euro-American settlement had been documented for the Cheesman Lake landscape prior to the Hayman Fire: a 1963 wildfire that affected around 20 ha before it was suppressed (Brown et al. 1999, Kaufmann et al. 2000). Detailed tree age data from other studies conducted in the landscape, as well as paired historical and recent photographs, document the dramatic increase in tree density due to the suppression of this and countless other ignitions during the period after Euro-American settlement (Kaufmann et al. 2000, 2001). Changing climate has also been cited as a driver of recent increases in wildfire frequency and size, and may be contributing to increases in severity as well (Westerling et al. 2006, Westerling 2016). The Colorado Front Range experienced a record drought during the months prior to the Hayman Fire, creating antecedent conditions conducive to severe burning (Bradshaw et al. 2003). Moreover, fire weather during the day that the Hayman Fire impacted the Cheesman Lake landscape was extreme, with relative humidity at the landscape's Remote Automated Weather Station reaching as low as 5\%, and wind speeds averaging $24 \mathrm{~km} \mathrm{hr}^{-1}$ to $32 \mathrm{~km} \mathrm{hr}^{-1}$ and gusting up to $72 \mathrm{~km} \mathrm{hr}^{-1}$ (Bradshaw et al. 2003, Finney et al. 2003). Nonetheless, the Hayman Fire's severity may have been moderated had forests been more open and heterogeneous, both within the landscape and on surrounding lands; the creation of such conditions via fuels reduction and restoration treatments has been widely shown to reduce fire severity in Western dry conifer forests, even under extreme weather conditions (e.g., Pollet and Omi 2002, Finney et al. 2005, Arkle et al. 2012, Safford et al. 2012, Waltz et al. 2014).

The loss of many old trees from the Cheesman Lake landscape is also notable from a conservation standpoint, as old trees, once abundant throughout Western dry conifer forests, are now rare due to past logging (Smith and Arno 1999, Kaufmann et al. 2000, Young- 
blood et al. 2004). Moreover, old trees are highly valued for the many ecological and cultural roles they play, including the provision of unique wildlife habitat, the sequestration of carbon, and scenic enhancement (Carey and Johnson 1995, Law et al. 2003, Luyssaert et al. 2008, Owen et al. 2009, Mazurek and Zielinski 2010). Uncharacteristic stand-replacing burning has similarly impacted other Western dry conifer forest landscapes with high concentrations of old trees, and such burning is considered to be one of the most significant threats to their continued persistence (Spies et al. 2006, Kolb et al. 2007, Harris and Taylor 2015). Prioritizing fuels reduction and restoration treatments for the remaining landscapes in which abundant old trees are still embedded may help minimize additional losses of these rare yet valuable landscape features (Spies et al. 2006, Kolb et al. 2007, Hood 2010, Lindenmayer et al. 2014).

\section{CONCLUSIONS}

Living old trees were well distributed and abundant in the 3400 ha Cheesman Lake landscape before the Hayman Fire, despite the fact that some stand-replacing burning had been a component of the landscape's historical mixed-severity fire regime (Brown et al. 1999, Huckaby et al. 2001). The nearly complete loss of old trees, many of which were located in areas with evidence of previous non-stand-replacing burning, leads us to conclude that the Hayman Fire's amount and extent of stand-replacing burning was unprecedented for the landscape over at least the last two to four centuries. This increased severity was likely the product of forest densification and homogenization across the landscape and the surrounding area after Euro-American settlement (Kaufmann et al. 2000, 2001), as well as of the extreme fire weather prior to and during the day that the landscape burned (Bradshaw et al. 2003, Finney et al. 2003). Furthermore, our study leads us to question the utility of severity classification systems juxtaposing low-severity with higher-severity burning, especially when examining long-term changes in fire severity for dry conifer forests historically regulated by higher-severity burning (e.g., Sherriff et al. 2014); such classification systems cannot account for changes occurring within the broad higher-severity class, such as increases in stand-replacing effects. Due to the opportunistic nature of our study, it was conducted in only one portion of one wildfire, and thus our ability to make broad inferences is limited. Nonetheless, this study makes a valuable contribution to the growing body of literature evaluating whether recent wildfires in Western dry conifer forests are burning in an uncharacteristic manner.

\section{ACKNOWLEDGEMENTS}

We gratefully acknowledge Denver Water for allowing us to conduct field work on their property in support of Huckaby et al. (2001), as well as G. Bradshaw, C. Deucy, H. Lyons, J. Stoker, and L. Triffleman for their assistance on that project. We thank J. Agee, G. Aplet, D. Binkley, J. Briggs, P. Fulé, B. Gannon, and two anonymous reviewers for providing helpful comments on earlier versions of this manuscript.

\section{LITERATURE CITED}

Applequist, M.B. 1958. A simple pith locator for use with off-center increment cores. Journal of Forestry 56: 141. 
Arkle, R.S., D.S. Pilliod, and J.L. Welty. 2012. Pattern and process of prescribed fires influence effectiveness at reducing wildfire severity in dry coniferous forests. Forest Ecology and Management 276: 174-184. doi: 10.1016/j.foreco.2012.04.002

Baisan, C.H., and T.W. Swetnam. 1990. Fire history on a desert mountain range, Rincon Mountain Wilderness, Arizona, USA. Canadian Journal of Forest Research 20: 1559-1569. doi: 10.1139/X90-208

Beaty, R.M., and A.H. Taylor. 2001. Spatial and temporal variation of fire regimes in a mixed conifer forest landscape, Southern Cascades, California, USA. Journal of Biogeography 28: 955-966. doi: 10.1046/j.1365-2699.2001.00591.x

Benavides-Solorio, J., and L.H. MacDonald. 2001. Post-fire runoff and erosion from simulated rainfall on small plots, Colorado Front Range. Hydrological Processes 15: 2931-2952. doi: 10.1002/hyp.383

Bradshaw, L., R. Bartlette, J. McGinely, and K. Zeller. 2003. Fire behavior, fuel treatments, and fire suppression on the Hayman Fire part 1: fire weather, meteorology, and climate. Pages 36-58 in: R.T. Graham, editor. Hayman Fire case study. USDA Forest Service General Technical Report RMRS-GTR-114, Rocky Mountain Research Station, Fort Collins, Colorado, USA.

Brown, P.M., M.R. Kaufmann, and W.D. Shepperd. 1999. Long-term, landscape patterns of past fire events in a montane ponderosa pine forest of central Colorado. Landscape Ecology 14: 513-532. doi: 10.1023/A:1008137005355

Brown, P.M., C.L. Wienk, and A.J. Symstad. 2008. Fire and forest history at Mount Rushmore. Ecological Applications 18: 1984-1999. doi: 10.1890/07-1337.1

Brown, P.M., M.A. Battaglia, P.J. Fornwalt, B. Gannon, L.S. Huckaby, C. Julian, and A.S. Cheng. 2015. Historical (1860) forest structure in ponderosa pine forests of the northern Front Range, Colorado. Canadian Journal of Forest Research 45: 1462-1473. doi: 10.1139/cjfr-2014-0387

Carey, A.B., and M.L. Johnson. 1995. Small mammals in managed, naturally young, and oldgrowth forests. Ecological Applications 5: 336-352. doi: 10.2307/1942026

Chambers, M.E., P.J. Fornwalt, S.L. Malone, and M.A. Battaglia. 2016. Patterns of conifer regeneration in severely burned ponderosa pine-dominated forests of the Colorado Front Range. Forest Ecology and Management 378: 57-67. doi: 10.1016/j.foreco.2016.07.001

Dillon, G.K., Z.A. Holden, P. Morgan, M.A. Crimmins, E.K. Heyerdahl, and C.H. Luce. 2011. Both topography and climate affected forest and woodland burn severity in two regions of the western US, 1984 to 2006. Ecosphere 2: 130. doi: 10.1890/ES11-00271.1

Everett, R.L., R. Schellhaas, D. Keenum, D. Spurbeck, and P. Ohlson. 2000. Fire history in the ponderosa pine/Douglas-fir forests on the east slope of the Washington Cascades. Forest Ecology and Management 129: 207-225. doi: 10.1016/S0378-1127(99)00168-1

Finney, M.A., C.W. McHugh, R. Bartlette, K. Close, and P. Langowski. 2003. Fire behavior, fuel treatments, and fire suppression on the Hayman Fire part 2: description and interpretations of fire behavior. Pages 59-95 in: R.T. Graham, editor. Hayman Fire case study. USDA Forest Service General Technical Report RMRS-GTR-114, Rocky Mountain Research Station, Fort Collins, Colorado, USA.

Finney, M.A., C.W. McHugh, and I.C. Grenfell. 2005. Stand- and landscape-level effects of prescribed burning on two Arizona wildfires. Canadian Journal of Forest Research 35: 17141722. doi: $10.1139 / \mathrm{x} 05-090$ 
Fornwalt, P.J., M.R. Kaufmann, L.S. Huckaby, J.M. Stoker, and T.J. Stohlgren. 2003. Non-native plant invasions in managed and protected ponderosa pine-Douglas-fir forests of the Colorado Front Range. Forest Ecology and Management 177: 515-527. doi: 10.1016/S03781127(02)00456-5

Fornwalt, P.J., M.R. Kaufmann, L.S. Huckaby, and T.J. Stohlgren. 2009. Effects of past logging and grazing on understory plant communities in a montane Colorado forest. Plant Ecology 203: 99-109. doi: 10.1007/s11258-008-9513-z

Fornwalt, P.J., M.R. Kaufmann, and T.J. Stohlgren. 2010. Impacts of mixed severity wildfire on exotic plants in a Colorado ponderosa pine-Douglas-fir forest. Biological Invasions 12: 2683-2695. doi: 10.1007/s10530-009-9674-2

Fulé, P.Z., M.M. Moore, and W.W. Covington. 1997. Determining reference conditions for ecosystem management in southwestern ponderosa pine forests. Ecological Applications 7: 895908. doi: 10.1890/1051-0761(1997)007[0895:DRCFEM]2.0.CO;2

Fulé, P.Z., and W.W. Covington. 1999. Fire regime changes in La Michilía Biosphere Reserve, Durango, Mexico. Conservation Biology 13: 640-652. doi: 10.1046/j.1523-1739. 1999.97512.x

Fulé, P.Z., J. Villanueva-Díaz, and M. Ramos-Gómez. 2005. Fire regime in a conservation reserve in Chihuahua, Mexico. Canadian Journal of Forest Research 35: 320-330. doi: 10.1139/x04-173

Graham, R., M. Finney, C. McHugh, J. Cohen, D. Calkin, R. Stratton, L. Bradshaw, and N. Nikolov. 2012. Fourmile Canyon Fire findings. USDA Forest Service General Technical Report RMRS-GTR-289, Rocky Mountain Research Station, Fort Collins, Colorado, USA.

Guiterman, C.H., E.Q. Margolis, and T.W. Swetnam. 2015. Dendroecological methods for reconstructing high-severity fire in pine-oak forests. Tree-Ring Research 71: 67-77. doi: 10.3959/1536-1098-71.2.67

Harris, L., and A.H. Taylor. 2015. Topography, fuels, and fire exclusion drive fire severity of the Rim Fire in an old-growth mixed-conifer forest, Yosemite National Park, USA. Ecosystems 18: 1192-1208. doi: 10.1007/s10021-015-9890-9

Heyerdahl, E.K., K. Lertzman, and C.M. Wong. 2012. Mixed-severity fire regimes in dry forests of southern interior British Columbia, Canada. Canadian Journal of Forest Research 42: 8898. doi: 10.1139/x11-160

Hood, S.M. 2010. Mitigating old tree mortality in long-unburned, fire-dependent forests: a synthesis. USDA Forest Service General Technical Report RMRS-GTR-238, Rocky Mountain Research Station, Fort Collins, Colorado, USA.

Huckaby, L.S., M.R. Kaufmann, J.M. Stoker, and P.J. Fornwalt. 2001. Landscape patterns of montane forest age structure relative to fire history at Cheesman Lake in the Colorado Front Range. Pages 19-27 in: R.K. Vance, W.W. Covington, and C.B. Edminster, editors. Ponderosa pine ecosystems restoration and conservation: steps toward stewardship. USDA Forest Service Proceedings RMRS-P-22, Rocky Mountain Research Station, Ogden, Utah, USA.

Huckaby, L.S., M.R. Kaufmann, P.J. Fornwalt, J.M. Stoker, and C. Dennis. 2003. Identification and ecology of old ponderosa pine trees in the Colorado Front Range. USDA Forest Service General Technical Report RMRS-GTR-110, Rocky Mountain Research Station, Fort Collins, Colorado, USA.

Iniguez, J.M., T.W. Swetnam, and C.H. Baisan. 2009. Spatially and temporally variable fire regime on Rincon Mountain, Arizona, USA. Fire Ecology 5(1): 3-21. doi: 10.4996/ fireecology.0501003 
Kaufmann, M.R., C.M. Regan, and P.M. Brown. 2000. Heterogeneity in ponderosa pine/Douglas-fir forests: age and size structure in unlogged and logged landscapes of central Colorado. Canadian Journal of Forest Research 30: 698-711. doi: 10.1139/x99-255

Kaufmann, M.R., P.J. Fornwalt, L.S. Huckaby, and J.M. Stoker. 2001. Cheesman Lake-a historical ponderosa pine landscape guiding restoration in the South Platte Watershed of the Colorado Front Range. Pages 9-18 in: R.K. Vance, W.W. Covington, and C.B. Edminster, editors. Ponderosa pine ecosystems restoration and conservation: steps toward stewardship. USDA Forest Service Proceedings RMRS-P-22, Rocky Mountain Research Station, Ogden, Utah, USA.

Keane, R.E., P.F. Hessburg, P.B. Landres, and F.J. Swanson. 2009. The use of historical range and variability (HRV) in landscape management. Forest Ecology and Management 258: 1025-1037. doi: 10.1016/j.foreco.2009.05.035

Keyser, T.L., L.B. Lentile, F.W. Smith, and W.D. Shepperd. 2008. Changes in forest structure after a large, mixed-severity wildfire in ponderosa pine forests of the Black Hills, South Dakota, USA. Forest Science 54: 328-338.

Kolb, T.E., J.K. Agee, P.Z. Fulé, N.G. McDowell, K. Pearson, A. Sala, and R.H. Waring. 2007. Perpetuating old ponderosa pine. Forest Ecology and Management 249: 141-157. doi: 10.1016/j.foreco.2007.06.002

Landres, P.B., P. Morgan, and F.J. Swanson. 1999. Overview and use of natural variability concepts in managing ecological systems. Ecological Applications 9: 1179-1188.

Law, B.E., O.J. Sun, J. Campbell, S. Van Tuyl, and P.E. Thornton. 2003. Changes in carbon storage and fluxes in a chronosequence of ponderosa pine. Global Change Biology 9: 510-524. doi: 10.1046/j.1365-2486.2003.00624.x

Lindenmayer, D.B, W.F. Laurance, J.F. Franklin, G.E. Likens, S.C. Banks, W. Blanchard, P. Gibbons, K. Ikin, D. Blair, L. McBurney, A.D. Manning, and J.A.R. Stein. 2014. New policies for old trees: averting a global crisis in a keystone ecological structure. Conservation Letters 7: 61-69. doi: 10.1111/conl.12013

Luyssaert, S., E.-D. Schulze, A. Börner, A. Knohl, D. Hessenmöller, B.E. Law, P. Ciais, and J. Grace. 2008. Old-growth forests as global carbon sinks. Nature 455: 213-215. doi: 10.1038/nature07276

Mazurek, M.J., and W.J. Zielinski. 2004. Individual legacy trees influence vertebrate wildlife diversity in commercial forests. Forest Ecology and Management 193: 321-334. doi: 10.1016/j.foreco.2004.01.013

Miller, J.D., H.D. Safford, M. Crimmins, and A.E. Thode. 2009. Quantitative evidence for increasing forest fire severity in the Sierra Nevada and southern Cascade Mountains, California and Nevada, USA. Ecosystems 12: 16-32. doi: 10.1007/s10021-008-9201-9

Miller, J.D., and H. Safford. 2012. Trends in wildfire severity: 1984 to 2010 in the Sierra Nevada, Modoc Plateau, and southern Cascades, California, USA. Fire Ecology 8(3): 41-57. doi: 10.4996/fireecology.0803041

Morgan, P., G.H. Aplet, J.B. Haufler, H.C. Humphries, M.M. Moore, and W.D. Wilson. 1994. Historical range of variability: a useful tool for evaluating ecosystem change. Journal of Sustainable Forestry 2: 87-111. doi: 10.1300/J091v02n01_04

MTBS [Monitoring Trends in Burn Severity]. 2015. Monitoring Trends in Burn Severity (MTBS). US Department of Agriculture, Geological Survey and US Department of Agriculture, Forest Service. <http://www.mtbs.gov>. Accessed 11 February 2015. 
NAIP [National Agriculture Imagery Program]. 2015. USDA National Agriculture Imagery Program (NAIP). US Department of Agriculture, Farm Service Agency. < http://www.fsa.usda. gov/programs-and-services/aerial-photography/imagery-programs/naip-imagery/index $>$. Accessed 10 March 2015.

O’Connor, C.D., D.A. Falk, A.M. Lynch, and T.W. Swetnam. 2014. Fire severity, size, and climate associations diverge from historical precedent along an ecological gradient in the Pinaleño Mountains, Arizona, USA. Forest Ecology and Management 329: 264-278. doi: 10.1016/j.foreco.2014.06.032

Owen, R.J., P.N. Duinker, and T.M. Beckley. 2009. Capturing old-growth values for use in forest decision-making. Environmental Management 43: 237-248. doi: 10.1007/s00267-0089133-3

Pollet, J., and P.N. Omi. 2002. Effect of thinning and prescribed burning on crown fire severity in ponderosa pine forests. International Journal of Wildland Fire 11: 1-10. doi: 10.1071/ WF01045

Romme, W.H., T.T. Veblen, M.R. Kaufmann, R. Sheriff, and C.M. Regan. 2003. Ecological effects of the Hayman Fire part 1: historical (pre-1860) and current (1860-2002) fire regimes. Pages 181-195 in: R.T. Graham, editor. Hayman Fire case study. USDA Forest Service General Technical Report RMRS-GTR-114, Rocky Mountain Research Station, Fort Collins, Colorado, USA.

Safford, H.D., J.T. Stevens, K. Merriam, M.D. Meyer, and A.M. Latimer. 2012. Fuel treatment effectiveness in California yellow pine and mixed conifer forests. Forest Ecology and Management 274: 17-28. doi: 10.1016/j.foreco.2012.02.013

Scholl, A.E., and A.H. Taylor. 2010. Fire regimes, forest change, and self-organization in an oldgrowth mixed-conifer forest, Yosemite National Park, USA. Ecological Applications 20: 362-380. doi: 10.1890/08-2324.1

Sherriff, R.L., and T.T. Veblen. 2006. Ecological effects of changes in fire regimes in Pinus ponderosa ecosystems in the Colorado Front Range. Journal of Vegetation Science 17: 705-718. doi: 10.1658/1100-9233(2006)17[705:eeocif]2.0.co;2

Sherriff, R.L., and T.T. Veblen. 2007. A spatially-explicit reconstruction of historical fire occurrence in the ponderosa pine zone of the Colorado Front Range. Ecosystems 10: 311-323. doi: $10.1007 / \mathrm{s} 10021-007-9022-2$

Sherriff, R.L., R.V. Platt, T.T. Veblen, T.L. Schoennagel, and M.H. Gartner. 2014. Historical, observed, and modeled wildfire severity in montane forests of the Colorado Front Range. PLoS ONE 9(9): e106971. doi: 10.1371/journal.pone.0106971

Smith, H.Y., and S.F. Arno, editors. 1999. Eighty-eight years of change in a managed ponderosa pine forest. USDA Forest Service General Technical Report RMRS-GTR-23, Rocky Mountain Research Station, Ogden, Utah, USA.

Spies, T.A., M.A. Hemstrom, A. Youngblood, and S. Hummel. 2006. Conserving old-growth forest diversity in disturbance-prone landscapes. Conservation Biology 20: 351-362. doi: 10.1111/j.1523-1739.2006.00389.x

Steel, Z.L., H.D. Safford, and J H. Viers. 2015. The fire frequency-severity relationship and the legacy of fire suppression in California forests. Ecosphere 6(1): 8. doi: 10.1890/ES1400224.1

Stephens, S.L., J.M. Lydersen, B.M. Collins, D.L. Fry, and M.D. Meyer. 2015. Historical and current landscape-scale ponderosa pine and mixed conifer forest structure in the southern Sierra Nevada. Ecosphere 6(5): 79. doi: 10.1890/ES14-00379.1 
Stokes, M.A., and T.L. Smiley. 1968. An introduction to tree-ring dating. University of Chicago Press, Illinois, USA.

Waltz, A.E., M.T. Stoddard, E.L. Kalies, J.D. Springer, D.W. Huffman, and A. Sánchez Meador. 2014. Effectiveness of fuel reduction treatments: assessing metrics of forest resiliency and wildfire severity after the Wallow Fire, AZ. Forest Ecology and Management 334: 43-52. doi: 10.1016/j.foreco.2014.08.026

Westerling, A.L., H.G. Hidalgo, D.R. Cayan, and T.W. Swetnam. 2006. Warming and earlier spring increase western US forest wildfire activity. Science 313: 940-943. doi: 10.1126/ science. 1128834

Westerling, A.L. 2016. Increasing western US forest wildfire activity: sensitivity to changes in the timing of spring. Philosophical Transactions of the Royal Society B 371: 20150178. doi: 10.1098/rstb.2015.0178

Williams, M.A., and W.L. Baker. 2012. Spatially extensive reconstructions show variable-severity fire and heterogeneous structure in historical western United States dry forests. Global Ecology and Biogeography 21: 1042-1052. doi: 10.1111/j.1466-8238.2011.00750.x

Youngblood A., T. Max, and K. Coe. 2004. Stand structure in eastside old-growth ponderosa pine forests of Oregon and northern California. Forest Ecology and Management 199: 191217. doi: 10.1016/j.foreco.2004.05.056 